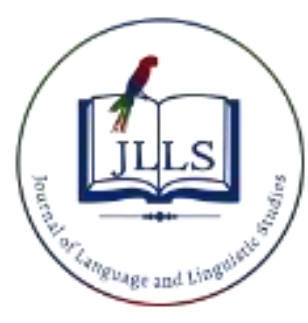

Available online at www.jlls.org

JOURNAL OF LANGUAGE

AND LINGUISTIC STUDIES

ISSN: $1305-578 \mathrm{X}$

Journal of Language and Linguistic Studies, 16(2), 661-683; 2020

\title{
The manifestations of micro and macro categories of pedagogical content knowledge in the practices of prospective EFL teachers
}

\author{
Arif Sarıçoban $^{\mathrm{a}}$ (D), Özkan Kırmızi \\ ${ }^{a}$ Şelcuk University, Konya, Turkey \\ ${ }^{b}$ Karabük University, Karabük, Turkey
}

\section{APA Citation:}

Sarıçoban, A., \& Kırmızı, Ö. (2020). The manifestations of micro and macro categories of pedagogical content knowledge in the practices of prospective EFL teachers. Journal of Language and Linguistic Studies, 16(2), 661-683.

Submission Date:15/04/2020

Acceptance Date:18/05/2020

\begin{abstract}
The present study was undertaken through a qualitative research model in order to examine which subcategories of Pedagogical Content Knowledge (PCK) emerged during the practicum process of four novice English teachers enrolled in a teaching certificate (formation) program at a public university. The teaching sessions of four prospective teachers (PTs) were recorded and follow-up interviews were conducted with the prospective teachers. Stimulated recall technique was used in the interviews. Each prospective teacher was observed for four times and the lessons conducted by prospective teachers were recorded. The PCK categorization suggested by Moradkhani et al. (2013) was utilized. They categorized PCK in 8 macro categories with accompanying micro categories. The study was conducted throughout one semester in which the novice teachers were supposed to complete their practicum. The results indicated that knowledge of students is extremely important in the language teaching process, which is followed by knowledge of transferring knowledge and knowledge of teaching techniques. Further, findings also indicate that PTs need development in knowledge of language, knowledge of language teaching methods, and knowledge of linguistics. PTs must develop insight into how to provide effective input.
\end{abstract}

(C) 2020 JLLS and the Authors - Published by JLLS.

Keywords: micro and macro categories, pedagogical content knowledge, novice EFL teachers, input, language teaching methods

\section{Introduction}

"Unless a teacher is a student of teaching, he or she may continue to improve in the mechanics of school management, but he or she cannot grow as a teacher" (Dewey, 1904, p. 15).

There is no doubt that pre-service teacher education plays a crucial role in preparing qualified teachers (Spear \& da Costa, 2018; Tsiotakis \& Jimoyiannis, 2016). Through these programs, pre-service

\footnotetext{
${ }^{1}$ Corresponding author. Tel.: +506 5339044

E-mail address: ozkankirmizi@gmail.com
} 
teachers build up their self-confidence, expand their knowledge base and thus take the necessary steps in their professional development. The UNESCO and countries around the world all put great effort to teacher training and adopt various ways to promote professional development of teachers (Ariffin, Bush, \& Nordin, 2018; Barnes, et al., 2018). Therefore, teacher education programs mediate between teacher candidates and the development of pedagogical content knowledge.

The term pedagogical content knowledge was put forward by Shulman (1986) as a part of his teacher knowledge base, which also include subject matter content knowledge, curricular knowledge, and knowledge of social and contextual dimensions, which was added to the framework later by Shulman (1987). The present study will only focus on the manifestations of pedagogical content knowledge.

Recently, concepts like content knowledge (a form of knowledge that is shared by everybody who knows a particular subject matter), specialized content knowledge (knowledge of the subject matter that is uniquely possessed by teachers), knowledge of students, and knowledge of teaching were added to the concept of PCK by Ball et al. (2008). Literature reveals the significance of teacher knowledge and its relation to student learning (Darling-Hammond \& Bransford, 2007; Gitomer \& Zisk, 2015; Grossman $\&$ McDonald, 2008). Studies indicate that vital role teacher knowledge plays in maintaining the teaching and learning process (e.g., Berliner, 2004).

Although various categorizations have been put forward as to pedagogical content knowledge, the basic features of PCK remain unchanged (Moradkhani et al. 2013) and these categorizations enabled researchers to study PCK for different subject matters. Gatbonton's (1999) study can be taken as one of the earliest studies that try to categorize PCK. Mullock (2006) also came up with similar results compared to Gotbanton's (1999) study. In a more recent study, Akbari and Dadvand (2011) studied the differences in the pedagogical thought units of teachers as a function of their formal teacher education and found that the affective category manifested the most differences and M.A. teachers far outperformed B.A. teachers in producing pedagogical thoughts. As can be seen, the issue of PCK has been on the agenda of researchers for a long time.

In the present study, the categorization included in Moradkhani et al's stud (2013) was used. Their categorization includes 8 macro categories and a number of micro categories under each macro category. The 8 macro categories and their micro strategies are as follows: (1) Knowledge of language and related discipline (knowledge of English language (proficiency), knowledge of educational psychology, knowledge of sociology, knowledge of linguistics, etc.), (2) knowledge of ELT theories, skills, and techniques (knowledge of teaching skills and components, knowledge of ELT theories, knowledge of language teaching methods, etc.), (3) knowledge of context and social relations (knowledge of students, knowledge of educational policies, goals, and objectives, etc.), (4) knowledge of class, time, and learning management (knowledge of transferring information, knowledge of responding to students' questions, knowledge of classroom management, etc.), (5) knowledge of research and professional development (knowledge of academic resources, knowledge of materials, knowledge of professional development, etc.), (6) knowledge of practicum (knowledge of practical demonstration of teaching, knowledge of connecting theory and practice, etc.) (7) knowledge of students and their assessment (knowledge of motivating students, knowledge of students' needs, etc.), and (8) knowledge of reflective and critical teaching (knowledge of creativity, knowledge of oneself, knowledge of fostering reflective teaching, etc.). The reason for the adoption of this categorization is that it covers a wide range of components.

The significance of PCK stem from the fact that, as was proposed by Shulman (1987), it may be taken as a sing of teaching expertise. There are a number of scholars who put emphasis on this concept as a framework for the efficiency of teachers (Akbari \& Dadvand, 2014). Therefore, it can be posited 
that it is a valid area of study. Studies like the present one are necessary because contexts where learning and teaching take place are many and varied. Salter \& Kothari (2016., p. 4) put forward that practice:

... is not made up of easily identified and neatly packaged problems with corresponding evidencebased solutions. The scope of practice, the problems and challenges faced by practitioners, are often greater than can be addressed by the direct application of research-based evidence alone. Instead, other forms of knowledge grounded in the experience of practice itself are required, in addition to research-based evidence, in order to address complex, uncertain or ill-defined situations encountered within the practice environment.

Therefore, it is vital to focus on classroom peculiarities in terms of understanding the manifestations of PCK in real settings. Another important point is that the practicum process is the "the longest and most intensive exposure to the teaching profession" for teacher candidates (Cohen, et al., 2013, p. 345). This also makes it worth studying.

\subsection{Pedagogical content knowledge}

Pedagogical content knowledge was defined (PCK) by Shulman (1987) as follows: "it represents the blending of content and pedagogy into an understanding of how particular topics, problems, or issues are organized, represented, and adapted to the diverse interests and abilities of learners, and presented for instruction" (p.8). According to Shulman (1987), it serves as the "category most likely to distinguish the understanding of the content specialist from that of the pedagogue" (p. 8). Mullock (2006) defined PCK as "... accumulated knowledge about the act of teaching, including the goals, procedures, and strategies which form the basis of what teachers do in the classroom" (p. 48). These definitions imply that PCK is " $\ldots$ both an external and internal construct, as it is constituted by what a teacher knows, what a teacher does, and the reasons for the teacher's actions" (Baxter and Lederman 1999, p. 158). Hence, PCK can be conceptualized as both teachers' understanding and their action. Shulman's (1987) categorization of PCK remains prominent because "it represents the blending of content and pedagogy into an understanding of how particular topics, problems, or issues are organized, represented and adapted to the diverse interests and abilities of learners, and presented for instruction" (p. 8).

PCK basically consists of knowledge on the parts of teachers as regards; (a) how their students learn specific subject matter, (b) the difficulties or misconceptions students may have regarding this subject matter, and (c) their knowledge of instructional strategies, such as representations (e.g. models, metaphors) and activities (e.g. explications, experiments) to teach this specific subject matter. These categorizations are inextricably linked. To sum up, it can be viewed as "the complex ways that teachers represent information for learners to understand ...” (Redmond \& Peledp; 2018, p.2).

Accumulated literature on PCK indicates that contextual and personal factors shape PCK to a certain extent. In this vein, Van Driel \& Berry (2010; p. 659) has suggested that "the development of PCK is perhaps best viewed as a complex interplay between knowledge of subject matter, teaching and learning, and context, and the way in which teachers combine and use this knowledge to express their expertise." Yet, studies that focus on the developmental stages of PCK are rather limited (Dirk et al, 2017). As such, one of the aims of the present study is to sketch out the developmental stages of PCK within the context of practicum.

\subsection{The rationale behind the study}

One reason why the study focuses on the emergence of the micro and macro categories of PCK is that investigating the practice produces highly valuable data and this has been the trend in social sciences 
in recent years (Miettinen, 2009). Human action stems from 'activity of separate individuals depends on their place in society, on the conditions that fall to their lot and on idiosyncratic, individual factors' (Leont'ev, 1981, p. 47). Studies conducted up to now clarify various forms of teacher collaboration (Lau \& Stille, 2014; Vangrieken et al., 2015), yet there seems to be a scarcity of research on the actual manifestations of PCK in school context. Therefore, it is critical to study the practice to get valuable data.

The present study stands out in that it is based on qualitative paradigm and utilizes observations. The aim of the present study is find out which micro and macro categories, suggested by Moradkhani et al (2013), emerge in the actual lessons of pre-service teachers. In terms of the situation in Turkey, Kömür (2010) states that despite positive developments there is still a disconnection between theory and practice, and this entails focusing on the empowerment of pre-service EFL teachers regarding the complexities of the classroom. With regard to this, the literature indicates the pedagogical value of mentoring. Along with this, there are also a number of problems novice teachers go through, which are primarily related to classroom management, extensive use of L1, lack of knowledge on ELT methods or theories, etc. Despite these, there seems to be a lack of research in this area. Therefore, the present study aims to provide insights in this regard and contribute to the existing body of knowledge.

Based on the research on L2 teacher education, Freeman (2002) proposed a reconceptualization of the knowledge base of L2 teachers. As a result, one line of research has focused on investigating L2 teachers' pedagogical content knowledge as part of how teachers think and work. Yet, the issue of how L2 teachers' cognitions are developed does not seem to have received satisfactory level of attention on the research agenda. Furthermore, although there are studies that focus on PCK, there seems to be a paucity of studies that focus on a qualitative analysis of PCK in the actual practices of novice teachers.

The role of mentoring has been accentuated by scholars. Some scholars view mentoring as a means of supporting pre-service teachers' professional learning and knowledge base by bringing together theory and practice. Mentors are expected to be a bridge in providing the link between theory and practice and thus be a model for novice teachers. According to Karimi and Norouzi (2017), the inclusion of the mentor and the mentee can be viewed as consistent with situated cognition. Based on situated cognition, it can be said that "knowledge entails lived practices, not just accumulated information, and the processes of learning are negotiated with people in what they do, through experiences in the social practices associated with particular activities" (Johnson, 2006, p. 237). Dennen (2004) also puts forward that "teaching and learning through cognitive apprenticeship requires making tacit processes visible to learners so they can observe and then practice them" (p. 814). In the present study, reflection sessions conducted by mentors, pre-service teachers, and the researcher.

\subsection{Literature review}

There is a number of recent studies that focus on PCK from different perspectives. Pedagogical thought categories, for example, were studied by Karimi (2011). This study found that significant differences among different teacher groups. In another study, van Compernolle and Henery (2015) found that the subject in their study achieved progress in terms of L2 pedagogical content knowledge. They evaluated the development of the PCK of the subject in their study from the Vygotskian genetic perspective. Jansen's (2014) study identified teacher education programs, additional learning experience, teaching experience, in-service professional development activities, and a working environment as fundamental sources of knowledge base construction for teachers. As for the structure of PCK, König et al (2016) found that teacher knowledge in TEFL is a multidimensional construct and it is closely related to both content knowledge and general pedagogical knowledge. In another recent study, Maaranen et al (2018) found that the primary concerns of novice teachers were related with how to execute the new job, how to conduct tasks, how to ensure the stability of the work. 
There are also several studies conducted in Turkey on the practicum process. For example, Celen and Akcan (2017) focused on an evaluation of an ELT practicum program from the perspectives of supervisors, student teachers and graduates. Their study concluded that the strong points of practicum process were having the chance to teach in classrooms, discussions and peer feedback, observing various grade levels, good relationship with cooperating teachers, and guidance by university supervisors. Their findings also indicated that there was a need for more observation, seeing different school contexts, more cooperation with cooperating teachers, and improvement in the assessment procedures, and technology use. Actually, these areas cover most of the sub-dimensions of PCK. In another study, Genç (2016) revealed that the strengths and weaknesses for prospective teachers ranged from classroom management to a lack of communication with cooperating teachers, and also to inadequate decisionmaking skills to handle the pressing circumstances involved in teaching.

\section{Method}

This study was designed as a qualitative case study involving four pre-service L2 teachers in their practicum within the scope of teacher education program. Gass (2015) states that qualitative approach is a peculiar means of inquiry in scholarly studies. In addition, Lantolf (2012) emphasizes the role of the social process in qualitative research and such studies are conducted within the context of sociocultural theory. Moreover, according to Creswell (2015), “... reality is better determined by different individual perspectives than one general explanation" (Creswell, 2015, p. 16). These justify the use of qualitative means of data collection.

\subsection{Participants and Research Setting}

The participants of the study were four pre-service teachers going through their practicum. The consents of pre-service teachers were obtained before the study was conducted. The participants are English Language and Literature department students who are taking their teacher certificate program. This program lasts for two semesters. In the first semester, students take courses like educational psychology, testing, teaching methods and techniques, etc. In the second semester of the teacher certificate program, students take two courses along with their practicum experience. The courses taken in the second semester are "materials design" and "Teaching language skills". The age range of the participants is between 22 and 23. None of them had experience or other professional relations with students and teaching before they started their teacher certificate program.

The practicum is a fourteen-week practicum, and candidate teachers are placed into schools and they are supposed to stay in the school one day of the week entering courses. During their stay, they observe different aspects of the instructional process that range from the implementation of activities to elements of classroom management. Each student is assigned to one mentor teacher at the practicum school and each mentor teacher has either three or four teacher candidates in their classrooms. Students are supposed to conduct lessons at least four times during this fourteen-week process, with the classroom teacher-mentor guiding them in implementing the curriculum. The present study focused on the manifestations of PCK in the practices of novice teachers.

The teaching hours of the participants were determined by the participants, the researcher, and the mentors. The researcher visited the classroom to observe the participants. The instruction generally followed the curriculum specified by the Ministry of Education. All the materials are provided by the ministry. The classes are equipped with smart boards. Pre-service teachers were warmed up to the actual teaching week by week. They taught short sessions before taking on a full-lesson teaching. As of the sixth week, they started their full-lesson teachings. Collaboration was ensured among mentors, the 
researcher, and the pre-service teachers in preparing the lessons. Before the participants conducted their lessons, they observed their mentors for four weeks.

\subsection{Instrument(s)}

Focus group interviews, stimulated recalls, reflection sessions, and video records, and evaluations provided by mentors were used to collect data. The participants' lessons were recorded, and stimulated recalls were conducted shortly after each lesson to discuss which aspects of PCK materialized in each lesson. Stimulated recall is "one of the few tools we have available for probing pedagogical knowledge" (Mullock, 2006, p. 52). To provide reliable data, stimulated recalls were conducted right after each lesson so that, as is pointed out by Gass and Mackey's (2000), no data would be lost. The videos consisted of 16 hours in total and the reflection sessions consisted of nearly 8 hours. The researcher observed and recorded 16 lessons given by the four participants. The videos were watched and discussed by the pre-service teacher, mentor, and the researcher after the instruction. In total, nearly 16 hours of video-recorded sessions were obtained. The mentors were included in the reflection sessions because, as is pointed out by Dennen (2004), mentors can provide explicit expert knowledge through verbal descriptions. A similar point was made by Freeman (1991), who suggested the language used by experienced teachers enable novice teachers to perceive the personal thoughts of pre-service teachers about teaching. According to Geerarerts et al. (2015) and Korhonen et al. (2017), mentoring provides a specifically dynamic and reciprocal collaboration.

In the present study, the classification of Moradkhani et al. (2013) was used. They categorized PCK under 8 macro categories, which have a number of related micro categories. The macro categories and their related micro categories are given in Table 1.

Table 1. Macro and micro categories of PCK offered by Moradkhani et al. (2013)

\begin{tabular}{ll}
\hline \multicolumn{1}{c}{ macro category } & \multicolumn{1}{c}{ micro categories } \\
\hline $\begin{array}{l}\text { 1. Knowledge of language } \\
\text { and related discipline }\end{array}$ & $\begin{array}{l}\text { knowledge of English language (proficiency), knowledge of educational } \\
\text { psychology, knowledge of sociology, knowledge of linguistics, knowledge of } \\
\text { testing, knowledge of psycholinguistics, knowledge of sociolinguistics, } \\
\text { knowledge of L1 (metalanguage), knowledge of ESP, knowledge of target } \\
\text { language culture, knowledge of teaching-related art }\end{array}$ \\
& $\begin{array}{l}\text { knowledge of teaching skills and components, knowledge of ELT theories, } \\
\text { knowledge of language teaching methods, knowledge of the philosophy of } \\
\text { teaching, knowledge of technical jargons, knowledge of teaching techniques, } \\
\text { knowledge of error correction, knowledge of classroom teaching, routines } \\
\text { thechniques } \\
\text { knowledge of ELT theory evaluation }\end{array}$
\end{tabular}

3 Knowledge of context and social relations

4 Knowledge of class, time, and learning management

5. Knowledge of research and professional development

6 Knowledge of practicum knowledge of students, knowledge of educational policies, goals, and objectives, knowledge of social relations (with colleagues), knowledge of consultation with colleagues

knowledge of transferring information, knowledge of responding to students' questions, knowledge of classroom management, knowledge of time management, knowledge of lesson plan, knowledge of student involvement, knowledge of successful classroom performance,

knowledge of academic resources, knowledge of materials, knowledge of professional development, knowledge of research, knowledge of new ideas, knowledge of technology use, knowledge beyond boundaries of books,

knowledge of practical demonstration of teaching, knowledge of connecting theory and practice, knowledge of provision of practical teaching experience, knowledge of research-practice connection, knowledge of assignment 
7 Knowledge of students and their assessment

8 Knowledge of reflective and critical teaching knowledge of motivating students, knowledge of students' needs, knowledge of assessing students, knowledge of the students' learning process, knowledge of students' emotional well-being, knowledge of students' prior knowledge, knowledge of feedback provision for students' performance, knowledge of a good teacher's characteristics

knowledge of creativity, knowledge of oneself, knowledge of provision of a good citizen model, knowledge of fostering reflective teaching

Since some of these categories were prepared thinking teacher educators, there are some categories such as knowledge of practicum that are not relevant for novice teachers. These categories were not included in the analysis. In addition, minor adaptations were made in the micro-categories. For example, categories knowledge of teaching techniques and knowledge of classroom teaching sound similar. So, they were considered as only one category.

\subsection{The use of video as a data collection tool}

The popularity of video as a data collection tool has substantially increased recently for social researchers who intend to study contexts such as classrooms in their natural conditions (Jewitt 2012; 2). There are several reasons that led to the popularity of the video. In the first place, it is portable and does not require much expertise. Secondly and more importantly, it makes it possible to collect natural data in naturally occurring environments and this enabled 'video revolution' (Knoblauch et al. 2006, 9) and a 'qualitative leap in social research' (Luckmann 2006, 30). It offers both temporal and visual material and provides "... a temporal and sequential record, offering information about an event as it unfolds moment-by-moment" (Kate, 2014, 6). Likewise, Admiraal \& Berry (2016) put forward that using video recordings enables researchers to include direct evidence of teaching and makes it possible to provide information on a wide range of competencies. This provides analytic and varied reflection.

Therefore, it is a valuable resource for classroom studies, especially for language teaching and learning environments where facial expressions and body language are at the forefront.

As for the utility of the video as a data collection tool, a number of researchers suggest that the data in the video recordings must be transcribed (Ericson, 2011; Duranti, 2006). Duranti (2006) states that social events may not be captured in their entirety by watching the video only. Therefore, in the present study, orthographic transcription was used. It is based on transcribing the video recordings into spoken language in a 'word-for-word' manner.

\section{Results}

The findings presented here are the macro and micro categories that manifested themselves in the practicum process of PTs. In this section, findings are presented in tables. In these tables, both mentors' / professors' focus and novice teacher' focus are given together. On the left side, we have mentors' / professors' focus for all the four preservice teachers for the given categories. On the right side, we have preservice teachers' focus on the same categories. The numbers indicate frequencies. 
Table 2. Knowledge of language and related discipline

\begin{tabular}{|c|c|c|c|c|c|c|c|c|c|c|}
\hline \multirow{3}{*}{$\begin{array}{l}\text { Knowledge of language and related } \\
\text { discipline }\end{array}$} & \multicolumn{5}{|c|}{$\begin{array}{l}\text { Mentors'/ professors' } \\
\text { focus }\end{array}$} & \multicolumn{5}{|c|}{$\begin{array}{l}\text { Pre-service teachers' } \\
\text { focus }\end{array}$} \\
\hline & PT1 & PT2 & PT3 & PT4 & Total & PT1 & PT2 & PT3 & PT4 & Total \\
\hline & & & & & & & & & & \\
\hline $\begin{array}{l}\text { Knowledge of English language } \\
\text { (proficiency, pronunciation, grammar, } \\
\text { etc.) }\end{array}$ & 6 & 8 & 4 & 4 & 23 & 2 & 3 & 4 & 4 & 13 \\
\hline $\begin{array}{l}\text { Knowledge of educational } \\
\text { psychology (establishing rapport, } \\
\text { understanding students feelings } \\
\text { thoughts, mood of the lesson) }\end{array}$ & 2 & 2 & 2 & 2 & 8 & 1 & - & 2 & 1 & 4 \\
\hline Knowledge of sociology & 1 & - & - & - & 1 & - & - & - & - & 0 \\
\hline Knowledge of linguistics & - & - & - & - & 0 & - & - & - & - & 0 \\
\hline Knowledge of testing & - & - & - & - & 0 & - & - & - & - & 0 \\
\hline $\begin{array}{l}\text { Knowledge of linguistics (which } \\
\text { linguistic items to teach or not to } \\
\text { teach) }\end{array}$ & 2 & 4 & 2 & 4 & 14 & 2 & 2 & 3 & 1 & 8 \\
\hline
\end{tabular}

As for knowledge of language and related discipline, the micro categories knowledge of psycholinguistics, knowledge of sociolinguistics, knowledge of L1 (metalanguage) knowledge of target language culture proved to be irrelevant on the part of PTs in the present study. That is to say, students did not reflect on these components. One striking point is that PTs do not seem to be aware of their language proficiency, including pronunciation, grammar, or vocabulary $(n=13)$. Mentors seem to be more concerned in this regard $(n=23)$. PTs were also less concerned with establishing rapport, understanding students feelings thoughts, mood of the lesson; that is, micro categories about knowledge of educational psychology $(n=4)$. In regard to the other aspects of knowledge of language and related discipline, namely knowledge of psycholinguistics, knowledge of sociolinguistics, and knowledge of L1 (metalanguage), no data emerged from the lessons of PTs.

One fundamental issue in this category concerns knowledge of linguistics. This covers issues like which topics to teach, in which order to teach linguistic items, and how much of the topic to teach. This aspect is closely related to the quality of the input provided by PTs. Out of the observations, it was clear that PTs fail to provide effective input for students.

PTs mainly relied on a deductive approach in their teaching and when inquired they stated that students were not ready for inductive learning. Yet, they were of the opinion that with inductive teaching students would learn better. Similarly, PTs did rarely do pair work or group work activities. 
Table 3. Knowledge of ELT theories, skills, and techniques

\begin{tabular}{|c|c|c|c|c|c|c|c|c|c|c|}
\hline & \multicolumn{5}{|c|}{$\begin{array}{l}\text { mentors' / professors' } \\
\text { focus }\end{array}$} & \multicolumn{5}{|c|}{$\begin{array}{l}\text { Pre-service teachers' } \\
\text { focus }\end{array}$} \\
\hline & PT1 & PT2 & PT3 & PT4 & Total & PT1 & PT2 & PT3 & PT4 & Total \\
\hline \multicolumn{11}{|l|}{$\begin{array}{l}2 \text { Knowledge of ELT theories, } \\
\text { skills, and techniques }\end{array}$} \\
\hline $\begin{array}{l}\text { knowledge of teaching skills and } \\
\text { components }\end{array}$ & 4 & 2 & 6 & 2 & 14 & 1 & 2 & 2 & 2 & 7 \\
\hline $\begin{array}{l}\text { knowledge of ELT theories (use of } \\
\text { L1) }\end{array}$ & 4 & 3 & 3 & 3 & 13 & - & 1 & 1 & 1 & 3 \\
\hline $\begin{array}{l}\text { knowledge of language teaching } \\
\text { methods (examples, exercises, etc.) }\end{array}$ & 4 & 5 & 2 & 4 & 15 & 1 & 2 & 2 & 3 & 8 \\
\hline $\begin{array}{l}\text { knowledge of the philosophy of } \\
\text { teaching }\end{array}$ & - & - & - & - & - & - & -- & - & - & - \\
\hline $\begin{array}{l}\text { knowledge of teaching techniques } \\
\text { (eye contact, location in the class, } \\
\text { pacing, summary making) }\end{array}$ & 9 & 6 & 5 & 8 & 28 & 3 & 2 & 6 & 4 & 15 \\
\hline knowledge of error correction & 2 & 4 & 4 & 1 & 11 & 2 & 3 & 2 & 2 & 9 \\
\hline $\begin{array}{l}\text { routines knowledge of ELT theory } \\
\text { evaluation }\end{array}$ & - & - & - & - & - & - & - & - & - & - \\
\hline
\end{tabular}

As for knowledge of ELT theories, skills, and techniques, the most rated micro category was knowledge of teaching techniques (eye contact, location in the class, pacing, summary making). It appeared 28 times in the evaluation of professors / mentors, and 15 times in the evaluation of PTs. The second most rated category was knowledge of language teaching methods (examples, exercises, etc.), which was rated 15 times by professors / mentors and 8 times by PTs.

Regarding knowledge of teaching skills and components, PTs do not seem to have any idea of handling the four skills. They mostly cared for grammar and vocabulary. They also failed to provide inductive teaching at times when they could. They stuck to deductive teaching.

In general, PTs L2 use on the premise that students will not understand them. One of the PTs stated that "It is not possible to use L2 when teaching grammar". However, the other PT stated that "At first, it was difficult, but some time later students got used to hearing English". One of the PTs stated the following:

L2 use is very important. Using English in the class. They are not used to it. We have been learning English, but we don't understand it. At first, I can use demos and gestures. I believe that if I start in English, they will get used to it.

As for time management, most of the time PTs did not turn out to be precise in terms of effective time use. This is highly important in that when time management goes wrong, PTs lose their temper and suffer from a breakdown.

PTs had hard times with examples. To be more specific, their examples were not exemplary most of the time. At others, they were too few. Concerning knowledge of teaching skills and components, it can be said that PTs only focused on the teaching of grammar structures and vocabulary. Language skills like reading, listening, speaking, or writing received very little attention from PTs in the present study.

Regarding error correction, it can be said that PTs performed effective corrections in the class; they were timely. However, most of the time they missed some important points. For example, students kept making pronuncation errors such as the wrong pronunciation of the (ing) sound, but PTs did not correct them. The reason for this is that PTs also do not have sufficient awareness as this. In addition, they also failed to provide effective input. For example, when working on houses, they failed to teach the difference between a house and a flat. Another example may be the presentation of hours. When 
presenting hours, the PTs failed to provide the rules effectively. They also wasted too much time on what "short arm" and "long arm".

The following quote from one of the participants in the very first week reveals the problems novice teachers had at the beginning:

I thought that they knew the subject beforehand. Participation was low along with motivation. They did not answer questions. They did not care for what I was writing on the board. The lesson started very well but some time later things went wrong. Their note-taking took so long. I don 't think they understood how to say or write "hours" Participation is low. I was not able to figure out what they can do and what they cannot do. When I was giving the role, I used "minute + past / to + hour". But this turned out be rather confusing on the part of the students. Some students did not care for what I was doing. The transitions were vague.

This quotation reflects the importance of "knowledge of students", "knowledge of content" and "knowledge of conducting lesson".

Table 4. Knowledge of context and social relations

\begin{tabular}{|c|c|c|c|c|c|c|c|c|c|c|}
\hline & \multicolumn{5}{|c|}{$\begin{array}{l}\text { mentors' / professors' } \\
\text { focus }\end{array}$} & \multicolumn{5}{|c|}{$\begin{array}{l}\text { Pre-service teachers' } \\
\text { focus }\end{array}$} \\
\hline & PT1 & PT2 & PT3 & PT4 & Total & PT1 & PT2 & PT3 & PT4 & Total \\
\hline $\begin{array}{l}3 \text { Knowledge of context and } \\
\text { social relations }\end{array}$ & 4 & 3 & 5 & 6 & 18 & 7 & 5 & 6 & 7 & 25 \\
\hline KIIOWIetge or studetits & & & & & 18 & 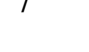 & 5 & 0 & 1 & \\
\hline knowledge of educational policies & 1 & - & - & - & 1 & - & - & - & - & - \\
\hline goals, and objectives & - & 1 & - & - & 1 & - & - & - & - & - \\
\hline knowledge of social relations & 1 & 2 & 3 & 2 & 8 & 2 & 3 & 2 & 3 & 10 \\
\hline
\end{tabular}

Table 4 presents the findings regarding knowledge of context and social relations. One of the most important micro categories in this category was knowledge of students, rated 18 times by professors / mentors and 25 times by PTs. All the novice teachers increasingly stressed the importance of knowing students. Another significant point for PTs was knowledge of social relations. They collaborated with their friends effectively. As for goals, and objectives, PTs tended to state the aims of lessons. However, they failed to grasp goals, and objectives of activities they provided. However, PTs do not seem to care for educational policies and goals, and objectives in general. As for knowledge of students, two of the participants stated the following:

We must definitely know our students.

The same happened to me. I have hard times in understanding whether they have understood or not. Every time we start teaching a topic, we must do a good review. 
Table 5. Knowledge of class, time, and learning management

\begin{tabular}{|c|c|c|c|c|c|c|c|c|c|c|}
\hline & \multicolumn{5}{|c|}{$\begin{array}{l}\text { mentors'/ professors' } \\
\text { focus }\end{array}$} & \multicolumn{5}{|c|}{$\begin{array}{l}\text { Pre-service teachers' } \\
\text { focus }\end{array}$} \\
\hline & PT1 & PT2 & PT3 & PT4 & Total & PT1 & PT2 & PT3 & PT4 & Total \\
\hline $\begin{array}{l}\text { Knowledge of class, time, and } \\
\text { learning management } \\
\text { knowledge of transferring information } \\
\text { presentation, use of board, PPP, } \\
\text { clarity of presentation, providing } \\
\text { effective exercises, use of voice, use } \\
\text { of body language) }\end{array}$ & 11 & 13 & 11 & 14 & 39 & 6 & 7 & 6 & 7 & 26 \\
\hline $\begin{array}{l}\text { knowledge of classroom management } \\
\text { (monitoring, pacing, tempo, } \\
\text { monitoring) }\end{array}$ & 9 & 12 & 10 & 10 & 41 & 6 & 4 & 5 & 6 & 21 \\
\hline knowledge of time management & 6 & 4 & 4 & 4 & 18 & 1 & 1 & 4 & 1 & 7 \\
\hline $\begin{array}{l}\text { knowledge of lesson plan } \\
\text { (contingency plan) }\end{array}$ & 8 & 3 & 4 & 4 & 19 & - & - & 1 & 1 & 2 \\
\hline knowledge of student involvement & 3 & 4 & 2 & 3 & 12 & 2 & 1 & 2 & - & 5 \\
\hline
\end{tabular}

Table 5 presents the findings about knowledge of class, time, and learning management. For this macro strategy, knowledge of classroom management (monitoring, pacing, tempo, monitoring) was the most rated category both by professors / mentors $(n=41)$ and PTs $(n=21)$. The second most rated category was knowledge of transferring information presentation, which was rated 39 times by professors / mentors and 26 times by PTs. The third category concerns knowledge of lesson plan (rated 19 times by professors / mentors) and knowledge of time management (rated 18 times by professors / mentors). These categories received less attention from PTs because they are not mostly aware of the effectiveness of plan and importance of time management.

When it coms to knowledge of student involvement, PTs cannot be said to have done their best to get students to participate lessons, yet they were not highly successful in getting students to participate. As a result, Pts endured serious psychological breakdown, indicating a highly fragile resilience.

Table 6. Knowledge of research and professional development

\begin{tabular}{|c|c|c|c|c|c|c|c|c|c|c|}
\hline & \multicolumn{5}{|c|}{$\begin{array}{l}\text { mentors'/ professors' } \\
\text { focus }\end{array}$} & \multicolumn{5}{|c|}{$\begin{array}{l}\text { Pre-service teachers' } \\
\text { focus }\end{array}$} \\
\hline & PT1 & PT2 & PT3 & PT4 & Total & PT1 & PT2 & PT3 & PT4 & Total \\
\hline $\begin{array}{l}\text { Knowledge of research and } \\
\text { professional development }\end{array}$ & & & & & & & & & & \\
\hline knowledge of academic resources & - & - & - & - & - & - & - & - & - & - \\
\hline knowledge of materials & 6 & 4 & 4 & 3 & 17 & 3 & 4 & 4 & 4 & 15 \\
\hline $\begin{array}{l}\text { knowledge of professional } \\
\text { development }\end{array}$ & - & - & - & - & - & - & - & - & - & - \\
\hline knowledge of research & - & - & - & - & - & - & - & - & - & - \\
\hline knowledge of new ideas & 2 & 2 & 2 & 2 & 8 & 2 & 2 & 1 & 1 & 6 \\
\hline knowledge of technology use & 3 & 3 & 3 & 3 & 12 & 4 & 3 & 4 & 4 & 15 \\
\hline
\end{tabular}

The results as to knowledge of research and professional development are given in Table 6. It can be seen that the micro categories that that were mentioned by PTs were knowledge of materials $(n=15)$, 
knowledge of new ideas $(n=6)$, knowledge of technology use $(n=15)$. Unfortunately, categories such as knowledge of academic resources, knowledge of professional development, knowledge of research did not receive any attention from PTs. Thankfully, one area of development was knowledge of materials. At the beginning of the process, PTs had very little idea of how to find, select, and use materials. However, through the end of the practicum they made great strides in finding, evaluating, and using materials.

Table 8. Knowledge of students and their assessment

\begin{tabular}{|c|c|c|c|c|c|c|c|c|c|c|}
\hline \multirow[b]{3}{*}{$\begin{array}{l}\text { Knowledge of students and their } \\
\text { assessment }\end{array}$} & \multicolumn{5}{|c|}{$\begin{array}{l}\text { mentors'/ professors' } \\
\text { focus }\end{array}$} & \multicolumn{5}{|c|}{$\begin{array}{l}\text { Pre-service teachers' } \\
\text { focus }\end{array}$} \\
\hline & PT1 & PT2 & PT3 & PT4 & Total & PT1 & PT2 & PT3 & PT4 & Total \\
\hline & & & & & & & & & & \\
\hline knowledge of motivating students & 2 & 2 & 2 & 3 & 9 & 2 & 3 & 2 & 4 & 11 \\
\hline knowledge of students' needs & - & - & - & - & - & - & - & - & - & - \\
\hline knowledge of assessing students & - & - & - & - & - & - & - & - & - & - \\
\hline $\begin{array}{l}\text { knowledge of the students' learning } \\
\text { process (monitoring, comprehension } \\
\text { checks) }\end{array}$ & 4 & 6 & 3 & 7 & 20 & 3 & 2 & 1 & 1 & 7 \\
\hline $\begin{array}{l}\text { knowledge of students' emotional } \\
\text { well-being }\end{array}$ & - & - & - & - & - & 1 & - & - & - & 1 \\
\hline $\begin{array}{l}\text { knowledge of students' prior } \\
\text { knowledge }\end{array}$ & 2 & 1 & 1 & 1 & 5 & 2 & 1 & - & - & 3 \\
\hline
\end{tabular}

PTs failed to focus on all the students. They mostly focused on participanting students, ignoring the others. They also failed to provide students attention before starting an activity or when transitioning between activities. Another point concerns pacing, tempo, and mood of lessons. Pacing was most of the time either too slow or too fast. When it comes to the mood of lessons, it can be said that PTs lost the mood from time to time due to lack of sufficient exercises.

PTs generally failed to reckon students' needs. Instead of tailoring the instruction based on the needs of students, they followed a certain path for presentation, and this did not prove to be effective. PTs also failed in relating and reviewing previous knowledge. For example, when teaching dates, the PT did not revise "the months".

Table 9. Knowledge of reflective and critical teaching

\begin{tabular}{|c|c|c|c|c|c|c|c|c|c|c|}
\hline & \multicolumn{5}{|c|}{$\begin{array}{l}\text { mentors' / professors' } \\
\text { focus }\end{array}$} & \multicolumn{5}{|c|}{$\begin{array}{l}\text { Pre-service teachers' } \\
\text { focus }\end{array}$} \\
\hline & PT1 & PT2 & PT3 & PT4 & Total & PT1 & PT2 & PT3 & PT4 & Total \\
\hline \multicolumn{11}{|l|}{$\begin{array}{l}\text { Knowledge of reflective and } \\
\text { critical teaching }\end{array}$} \\
\hline knowledge of creativity & 2 & 3 & 2 & 1 & 8 & 2 & 3 & 4 & 2 & 11 \\
\hline knowledge of oneself & 1 & 2 & 1 & 1 & 5 & 3 & 1 & 1 & 2 & 7 \\
\hline $\begin{array}{l}\text { knowledge of fostering reflective } \\
\text { teaching }\end{array}$ & 2 & 2 & 2 & 4 & 10 & 1 & 1 & 1 & 1 & 4 \\
\hline
\end{tabular}

Concerning knowledge of fostering reflective teaching, PTs stated that video-recording lessons and doing reflection sessions were highly effective for them to see their progress. They claimed that they would not have been able to become so aware of their strengths and weaknesses without such facilities. Another point stated by PTs was that it is a good idea to start the stimulated recall sessions, that is reflection, with PTs own evaluation.

Finally, when students were inquired in terms of knowledge of reflective and critical teaching, they saw the need for professional development. In a recent study, Kırmızı \& Tosuncuoğlu (2019) found that 
PTs wanted to improve themselves in terms of use of L1, material use and planning, the pace and mood of the lesson, error correction, content and grading, and classroom management. In the present study, the participants stated that they would like to develop themselves broadly in L2 use, materials developments, and classroom management.

\subsection{Focus group interviews}

As was stated, three focus group interviews were conducted within the context of the study. They all lasted around 40-55 minutes. They were conducted with all the pre-service teachers participating the study. Table 10 presents the general themes that emerged from the focus-group interview 1.

Table 10. The themes emerging from focus group interviews

\begin{tabular}{lr}
\hline General categories / Themes & f \\
\hline 1. Knowledge of language and related discipline & 3 \\
knowledge of psychology / pedagogy & 3 \\
knowledge of curriculum / technology & 2 \\
knowledge of rules / language & 2 \\
ll use & 1 \\
knowledge of language & 1 \\
knowledge of psychology & 1 \\
theory & 13 \\
total & 13
\end{tabular}

2. Knowledge of ELT theories, skills, and techniques

inductive vs. deductive teaching $\quad 3$

error correction $\quad 1$

authority 1

total $\quad 5$

3. Knowledge of class, time, and learning management

knowledge of participation / motivation $\quad 5$

classroom management $\quad 4$

knowledge of materials $\quad 3$

knowledge of disruptive behavior $\quad 2$

knowledge of classroom $\quad 2$

establishing rapport $\quad 1$

using literature 1

voice 1

summary making at the end of the lesson $\quad 1$

checking understanding / monitoring 1

establishing rapport 1

total $\quad 22$

4. Knowledge of students and their assessment

knowledge of students 11

time management / planning $\quad 5$

total 16

5. Knowledge of reflective and critical teaching

$\begin{array}{ll}\text { reflection } & 6\end{array}$

duration $\quad 3$

collaboration $\quad 2$

self-development / intellectual development 12

teachers as learners $\quad 1$

knowledge of teaching profession 1

total 15 
Knowledge of language and related discipline

Under the category of knowledge of language and related discipline, knowledge of psychology / pedagogy, knowledge of curriculum / technology were mentioned 3 times by PTs. Concerning knowledge of psychology, one of the participants stated the following:

Our mentor used students when she was teaching comparative \& superlative. I think this is not correct. Students may be psychologically affected. I saw that and I don't think I will use this in my future teaching career.

The other categories, knowledge of rules / language and L1 use were rated 2 times. Concerning L2 use, one of the participants stated the following:

At first, we had difficulty about this. They are puzzled when we spoke English. But we persisted and some time later they started to get used to it. and in closing weeks of the practicum, they were not complaining any more. The thing is that if they know that the teacher will use Turkish, they don't listen to the teacher speaking English.

As for the inductive and deductive teaching strategies, the pre-service teachers also mentioned the use of L1 in the classroom. In the school where the study was conducted, most English teachers prefer to use L1 in the lesson. They use L2 very rarely. The following quotations exemplifies the situation:

Another important point is that this must be done from the beginning of the term. Since the beginning of the term, their teachers have been using LI in lessons and the students were used to attending the lessons in their L1. As a result, they are not used to hearing English and this hinders the ability to elicit the rules; that is they cannot or don't have to elicit the rules themselves because they know that their teachers will use L1 in explanations. Therefore, the students do not bother themselves to try to understand L2. They already know that their teachers will sooner or later switch back to L1. In the future, the teacher should set the principles very clearly and stick to these principles.

\section{Knowledge of ELT theories, skills, and techniques}

Under the category of knowledge of ELT theories, skills, and techniques, the concept of inductive vs. deductive teaching was rated 3 times, error correction and authority were rated once. The pre-service teachers also brought about the inductive and deductive dichotomy. They stated that they had time to test both inductive and deductive procedures and they said that when they adopted a deductive approach, students could understand it better. Inductive teaching enables learners to retain knowledge longer.

With regard to the use of inductive and deductive strategies, the pre-service teachers stressed the role of knowing the class and knowing the students. One of the participants stated the following:

This depends on the class. Not all methods work in all classes. Some classes like the idea of starting with the rules. But in the other they immediately get bored when they see that the teacher goes deductive and starts the lesson with grammar rules. I think that we should get to know the students as soon as possible and design our lessons accordingly. To sum up, it depends on the class.

Knowledge of class, time, and learning management

For knowledge of class, time, and learning management, knowledge of participation / motivation was rated 5 times, classroom management 4 times, and knowledge of materials 3 times. This category was received 22 responses and turned out to be the most rated category by PTs. It seems that PTs are 
concerned about class procedures, time and learning management. The participants stated that classroom management starts at the door of the class and continues until the end. In addition, they view the expertise and subject matter knowledge of the teacher as vital components of classroom management. Regarding knowledge of participation / motivation, one of the participants stated the following:

Sometimes students are out of the mood. And on such days of lessons, students feel down and this makes the teacher down as well. This affected us seriously. When they were out of the mood, we were also demotivated. In such cases, teachers need to exert extra effort.

Moreover, for materials use, one of the participants stated the following:

Very important. At first, we had difficulties in terms of finding and deciding on the materials to be used in the class. But as time went on, we acquired awareness of what materials to use and how to use these materials. Moreover, to get the attention of students, we are supposed to use effective materials. We had smart boards at school and they were highly effective.

\section{Knowledge of students and their assessment}

Regarding knowledge of students and their assessment, knowledge of students was rated 11 times and time management / planning 5 times. Knowledge of students was one of the most highly rated areas by novice teachers. In general, they stressed the importance of knowing students not only for what kind of answers they will five, for potential discipline problems but also adjusting instructional materials for the level of students.

This is rather elusive. Sometimes we think that they understand most of the things. Sometimes, although they seem to have understood, they cannot provide the answers. When I ask them "Did you understand?", they don't say that they haven't understood.

Knowledge of reflective and critical teaching

Finally, for knowledge of reflective and critical teaching, the pre-service teachers did not say much about this. However, they pointed out that for professional development they were supposed to read academic articles.

\section{Duration of practicum}

Duration was one of the important points of discussion according to pre-service teachers. Almost all the teachers stressed that the practicum should be prolonged. Some of the novice teachers stated that the observation stage at the beginning of the practicum was too long, while some said that it was sufficient. The argument of those who stated that it was too long was that it is beneficial up to a certain extent. After that point, novice teachers need actual practice. One of the participants stated the following as to the duration of practicum:

Having the practicum in only one term is not enough. We lose a lot of time before we start the actual teachings and when we start it is nearly the end of the term. The practicum process can be conducted in two semesters. When I started to teach the lesson, since I did not know the atmosphere, I had hard times. I didn't know the students. 


\section{Reflection sessions}

Self-reflection was another area of concern for pre-service teachers. One of the participants stated that he had hard times in

Now, I can see that these reflection sessions are highly useful. Sitting around the table here with all other pre-service teachers and criticizing each other in an academic manner is highly beneficial. When we are in the class and teaching, we may not be able to notice what is going on. But, when we do it this way, we can clearly see our strengths and weaknesses. Furthermore, I think that these reflection sessions are even more important than the lesson itself.

Another participant stated the following in terms of the reflection sessions:

It is very good that you did these reflection sessions. It has been highly beneficial for use. We had a chance to see our mistakes from the eyes of other. Thus, we learn the correct practice, and this will enable us to be more effective for our students in the future.

Another participant stated the following as to the effectiveness of reflection sessions:

When we say our strengths and weaknesses by ourselves, it is much more beneficial. We learn a lot when we evaluate our practices by ourselves. These reflection sessions have been highly beneficial. One more point is that you let us start the reflection sessions with our own evaluations and this was very good because if you had started saying the negative aspects first I would have been influenced by your remarks and I wouldn't have been able to evaluate myself effectively. This way it was more memorable. And this taught me how to be reflective in the future.

In addition to these remarks, the participants also stated that being close friends was to their benefit. They had the opportunity to share the activities they were planning to do. One of the teachers also emphasized the view that collaboration was highly important.

Another novice teacher stated the following:

Starting from the positive points was highly useful. If you had started with the negative points about me, I would have been more nervous, and these reflection sessions would not have been so useful.

\section{Discussion}

The present study focused on the manifestations of PCK in real classroom settings conducted by prospective teacher during their practicum process. Novice teachers mostly focused on L2 use, knowledge of students, classroom management, and materials selection. One of the most striking findings of the present study was related to L2 use. At the beginning of the term, novice teachers resisted to using L2 in the class pleading that students do not understand them. However, as the term wore on, they exerted special effort for this and at the end promising results were obtained. Not only the students but also the novice teachers were observed to have highly positive attitudes towards the use of L2 in the class. In addition, PTs also made progress in finding, selecting, evaluating, and using materials and they came to realize the role of materials in the teaching process.

Professors / mentors' views were overwhelmingly higher than PTs own evaluations for most categories, such as knowledge of classroom management, for which the views of professors / mentors' 
views are higher. Issues like knowledge of time management, knowledge of lesson plan, and knowledge of student involvement were also among the highest issues rated both by professors and mentors. These findings indicate that PTs failed to see the importance of planning, effective time management, and knowledge of student involvement.

Thankfully, one area of development was knowledge of materials. At the beginning of the process, PTs had very little idea of how to find, select, and use materials. However, through the end of the practicum they made great strides in finding, evaluating, and using materials. Yet, although all the PTs in the present study are students of English Language and Literature, none of them thought of including literature in their lessons.

When it coms to knowledge of student involvement, PTs cannot be said to have done their best to get students to participate lessons. Another point that merits attention in this regard is that PTs endured serious psychological breakdown when students did not participate. Their resilience was very low.

Unfortunately, the study revealed that PTs' knowledge of English language is seriously insufficient. They have problems in most areas of langauge, primarily pronunciation. As a result of this, they fail to provide effective input for their students. It can be speculated that this is one of the most important reasons why language teaching practices sometimes fail to reach its aim. In-service teachers' input provision should definitely be studied. It is estimated that students do not most of the time receive effective input from their teachers.

A number of studies report insufficient content knowledge on the part of teachers as part of pedagogical content knowledge in terms of not only language teaching but also other areas. Moats and Foorman (2003), for example, found serious gaps in $144 \mathrm{~K}-4$ reading teachers' understanding of critical concepts in reading instruction. In science education, Özden (2008) reported insufficient content knowledge on the part of science teachers and $\mathrm{Wu}$ (2009) reported insufficient content knowledge among math teachers. In a similar vein, Kissau and Algozzine (2017) also reported that a sizeable number of foreign language teachers in the United States fail to demonstrate adequate oral proficiency. To be more particular, nearly half of the foreign language teacher candidates participating in Glisan et al's (2013) study could not meet the standards imposed by ACTFL's oral proficiency test, a standardized, computer-delivered test for the global assessment of listening ability.

As can be seen, proficiency, namely content knowledge in this case, is a point of discussion. In support to this, Tedick (2013) stated that "proficiency in the foreign language is an essential prerequisite for effective foreign language teaching because it is not feasible to implement communicative pedagogy or other approaches, such as content-based instruction (CBI), without advanced level proficiency" (p. 536). In a similar vein, Thames, and Phelps (2008) put forward that "teachers who do not themselves know a subject well are not likely to have the knowledge to help students learn this content" (p. 404). As such, the issue assumes great importance particularly as it is linked with students' performance. Gitomer et al. (2011) report that there are content-specific licensure tests requiring teacher candidates to demonstrate basic skills in content areas and they demonstrated that such tests are highly effective. Therefore, it can be suggested that EFL teachers be exposed to such tests before they start their careers.

The present study indicated that awareness in PCK is highly important, particularly in the technological era which we are living in as is put forward by Sarıçoban et al (2019). The fact that technology is at the disposal of teachers make continuous professional development a must as teachers are expected to ensure professional development continuously. Another point voiced by Balbay et al (2018) is that this professional development must be "sustainable" as there is a variety of English teacher programs at tertiary level. Therefore, teacher education programs must aim to increase pre-service EFL teachers' awareness in terms of PCK components.

The present study focused on the manifestation of PCK in the practices of prospective EFL teachers. The focus was primarily on which categories are used or needed more than the others. As such, the issue 
of whether the practicum process contributed to the development of PCK on the part of prospective teachers received little focus within the context of the present study. Therefore, future studies can be conducted on how the practicum process changes prospective EFL teachers' beliefs about PCK because there is considerable literature indicating that practicum has an impact on the belief systems (Gan, 2013; Yuan \& Lee, 2014) and future decisions or feelings of prospective teachers (Mau, 1997; Merç, 2015; Yan \& He, 2010).

Studies indicate the significance of context in which teachers work in the development of their PCK Sanchez and Borg 2014). Britt-Postholm (2019), for example, concluded that culture, structure and content must be in coordination to improve school-based development in teacher education. Therefore, qualitative studies can focus on the influence of context in the development or manifestation of PCK of teachers. Another suggestion could be empowering teacher educators' pedagogical content knowledge. This assumption is based on literature findings. Literature indicates that teacher educators have a strong influence on pre-service EFL teachers' pedagogical content knowledge and academic reflective practice knowledge (Goodwin et al., 2014; Shagrir, 2010), as well as their affective/ cognitive and academic aspects (Conklin, 2015). Therefore, the teacher educators are expected to support pre-service teachers both consciously and unconsciously through effective modelling (Goodwin et al., 2014; Al-Isa, 2017). As such, teacher educators pedagogical content knowledge could also be focused on, as was done by Moradkani et al. (2013).

\section{Ethics Committee Approval}

The author(s) confirm(s) that the study does not need ethics committee approval according to the research integrity rules in their country (Date of Confirmation: June 11, 2020).

\section{References}

Admiraal, W. \& Berry, A. (2016) Video narratives to assess student teachers' competence as new teachers, Teachers and Teaching, 22(1), 21-34.

Akbari, R., \& Dadvand, B. (2011). Does formal education make a difference? A comparison of pedagogical thought units of BA vs. MA teachers. Modern Language Journal, 95(1), 44-60.

Akbari, R., \& Dadvand, B. (2014). Pedagogical knowledge base: A conceptual framework for teacher admission. System, 42(1), 12-22

Al-Issa, A.S.M. (2017). Qualities of the professional English language teacher educator: Implications for achieving quality and accountability, Cogent Education, 4, 1-17.

Ariffin, T. F. T., Bush, T., \& Nordin, H. (2018). Framing the roles and responsibilities of excellent teachers: Evidence from Malaysia. Teaching and Teacher Education, 73, 14-23. https://doi.org/10.1016/j. tate.2018.03.005

Balbay, S., \& Pamuk, G., Temir, T. Doğan, C. (2018). Issues in pre-service and in-service teacher training programs for university English instructors in Turkey. Journal of Language and Linguistic Studies, 14(2), 48-60

Ball, D., Thames, M., \& Phelps, G. (2008). Content knowledge for teaching: What makes it special? Journal of Teacher Education, 59, 389-407. 
Barnes, A. E., Zuilkowski, S. S., Mekonnen, D., \& Ramos-Mattoussi, F. (2018). Improving teacher training in Ethiopia: Shifting the content and approach of pre-service teacher education. Teaching and Teacher Education, 70, 1-11. https://doi.org/10.1016/j.tate.2017.11.004

Baxter, J. A., \& Lederman, N. G. (1999). Assessment and measurement of pedagogical content knowledge. In J. Gess-Newsome \& N. G. Lederman (Eds.), Examining pedagogical content knowledge (pp.147-161). Dordrecht, The Netherlands: Kluwer

Britt Postholm, M. (2019). The teacher educator's role as enacted and experienced in school-based development, Teachers and Teaching, DOI: 10.1080/13540602.2019.1587403

Celen, K.M. \& Akcan, S. (2017). Evaluation of an ELT Practicum Programme from The Perspectives of Supervisors, Student Teachers and Graduates, Journal of Teacher Education and Educators, 6(3), 251-274.

Cohen, E., Hoz, R., \& Kaplan, H. (2013). The practicum in preservice teacher education: A review of empirical studies. Teaching Education, 24(4), 345-380

Conklin, H. (2015). Preparing novice teacher educators in the pedagogy of teacher education. Action in Teacher Education, 37, 317-333.

Creswell, J. W. (2015). A concise introduction to mixed methods research. Thousand Oaks, CA: SAGE.

Darling-Hammond, L., \& Bransford, J. (2007). Preparing teachers for a changing world: What teachers should learn and be able to do. San Francisco: Jossey-Bass.

Dennen, V. P. (2004). Cognitive apprenticeship in educational practice: Research on scaffolding, modeling, mentoring, and coaching as instructional strategies. In A. Jonassen (Ed.), Handbook of research on educational communications and technology (2nd ed., pp. 813e828). Mahwah, NJ: Erlbaum.

Dewey, J. (1904). The relation of theory to practice in education. In C. A. McMurry (Ed.), The relation of theory to practice in the education of teachers, third yearbook, National Society for the Scientific Study of Education, part I (pp. 9-30). Chicago: The University of Chicago Press.

Dirk S. Wsopawiro, Rosanne C. Zwart \& Jan H. van Driel (2017) Identifying pathways of teachers' PCK development, Teachers and Teaching, 23(2), 191-210, DOI: 10.1080/13540602.2016.1204286

Freeman, D. (2002). The hidden side of the work: Teacher knowledge and learning to teach. Language Teaching, 35, 1-13.

Gan, Z. (2013). Learning to teach English language in the practicum: What challenges do non-native ESL student teachers face? Australian Journal of Teacher Education, 38(3), 92-108

Gass, S. M., \& Mackey, A. (2000). Stimulated recall methodology in second language acquisition. Mahwah, NJ: Erlbaum

Gass, S.M. (2015). Methodologies of Second Language Acquisition, In Martha Bigelow and Johanna Ennser-Kananen (eds.) The Routledge handbook of educational linguistics, New York: Routledge.

Gatbonton, E. (1999). Investigating experienced ESL teachers' pedagogical knowledge. The Modern Language Journal, 83(1), 35-50.

Gitomer, D., Brown, T., \& Bonett, J. (2011). Useful signal or unnecessary obstacle? The role of basic skills tests in teacher preparation. Journal of Teacher Education, 62, 431-445.

Gitomer, D. H., \& Zisk, R. C. (2015). Knowing what teachers know. Review of Research in Education, $39,1-53$. 
Genç, Z. S. (2016). More practice for pre-service teachers and more theory for inservice teachers of English language. Procedia- Social and Behavioral Sciences, 232, 677-683.

Geerarerts, K., Tynjälä, P., Markkanen, I., Pennanen, M., Heikkinen, H. L. T., \& Gijbels, D. (2015). Peer-group mentoring as a tool for teacher development. European Journal of Teacher Education, $38,358-377$.

Goodwin, A., Smith, L., Souto-Manning, M., Cheruvu, R., Tan, M., Reed, R., \& Taveras, L. (2014). What should teacher educators know and be able to do? Perspectives from practicing teacher educators. Journal of Teacher Education, 65, 284-302

Freeman, D. (1991). To make the tacit explicit": Teacher education, emerging discourse, and conceptions of teaching. Teaching and Teacher Education, 7, 439-454.

Jansem, A. (2014). Exploring Non-Native EFL Teachers' Knowledge Base: Practices and Perceptions, International Journal of Applied Linguistics \& English Literature, 3(6), 252-259.

Jewitt, C. (2008). Technology, Literacy and Learning: A Multimodal Perspective. London: Routledge.

Johnson, K. E. (2006). The sociocultural turn and its challenges for second language teacher education. TESOL Quarterly, 40(1), 235-257.

Karimi, M.N. and Norouzi, M. (2017). Scaffolding teacher cognition: Changes in novice L2 teachers' pedagogical knowledge base through expert mentoring initiatives, System, 65, 38-48.

Kate, C. (2014). Multimodal transcription of video: examining interaction in Early Years classrooms, Classroom Discourse, 5(1), 6-21, DOI: 10.1080/19463014.2013.859846

Kırmızı, Ö. \& Tosuncuoglu, İ. (2019). Becoming Reflective Practitioners: A Case Study of Four Beginning Pre-service EFL Teachers in Turkey, English Language Teaching, 12(4), 127-138.

Kissau, S. \& Algozzine, B. (2017). Effective Foreign Language Teaching: Broadening the Concept of Content Knowledge, Foreign Language Annals, 50(1), 114-134.

Knoblauch, H., B. Schnettler, J. Raab, and H. Soeffner. (2006). Video Analysis - Methodology and Methods. Frankfurt: Peter Lang.

Korhonen, H., Heikkinen, H. L. T., Kiviniemi, U., \& Tynjälä, P. (2017). Student teachers' experiences of participating in mixed peer mentoring groups of in-service and pre-service teachers in Finland. Teaching and Teacher Education, 61, 153-163.

Kömür, Ş. (2010) Teaching knowledge and teacher competencies: a case study of Turkish preservice English teachers, Teaching Education, 21:3, 279-296, DOI: 10.1080/10476210.2010.498579

König, J., Lammerding, S., Nold, G. Rohde, A. Strauß, S., and Tachtsoglou, S. (2016). Teachers' Professional Knowledge for Teaching English as a Foreign Language: Assessing the Outcomes of Teacher Education, Journal of Teacher Education, 67(4) 320-337.

Lantolf, J. 2012. Sociocultural theory: A dialectical approach to L2 research. In S. Gass and A. Mackey, (Eds.), The Routledge handbook of second language research (pp. 56-72). New York: Routledge.

Lau, S. M. C., \& Stille, S. (2014). Participatory research with teachers: Toward a pragmatic and dynamic view of equity and parity in research relationships. European Journal of Teacher Education, 37, $156-170$

Leont'ev, A. N. (1981). The problem of activity in psychology. In J. V. Wertsch (Ed.), The concept of activity in soviet psychology (pp. 37-71). Armonk, NY: M.E. Sharpe. 
Loughran, J. (2019). Pedagogical reasoning: the foundation of the professional knowledge of teaching, Teachers and Teaching, 1-13, DOI: 10.1080/13540602.2019.1633294.

Luckmann, T. (2006). Some Remarks on Scores in Multimodal Sequential Analysis. In Video AnalysisMethodology and Methods, Hubert Knoblauch, Bernt Schnettler, Jürgen Raab and Hans-Georg Soeffner (Eds.), Frankfurt: Peter Lang.

Maaranen, K., Kynäslahti, H. Byman, R., Jyrhämä, R. \& Sintonen, S. (2019): Teacher education matters: Finnish teacher educators' concerns, beliefs, and values, European Journal of Teacher Education, DOI: 10.1080/02619768.2019.1566317

Mau, R. Y. (1997) Concerns of student teachers: Implications for improving the practicum. Asia-Pacifc Journal of Teacher Education, 25(1), 53-65.

Merç, A. (2015). Assessing the performance in EFL teaching practicum: Student teachers' views. International Journal of Higher Education, 4(2), 44-56.

Mietinnen, R. (2009). Dialogue and creativity. Activity theory in the study of science, technology and innovations. Berlin: Lehmanns Media.

Moats, L., \& Foorman, B. (2003). Measuring teachers' content knowledge of language and reading, Annals of Dyslexia, 53, 23-45.

Moradkhani, S., Akbari, R., Ghafar Samar, R., \& Kiany, G. R. (2013). English Language Teacher Educators' Pedagogical Knowledge Base: The Macro and Micro Categories. Australian Journal of Teacher Education, 38(10). 123-141.

Mullock, B. (2006). The pedagogical knowledge base of four TESOL teachers. The Modern Language Journal, 90, 48-66.

Ozden, M. (2008). The effect of content knowledge on pedagogical content knowledge: The case of teaching phases of matters. Kuram ve Uygulamada Egitim Bilimleri, 8, 611-645

Redmond, P. \& Peled, Y. (2018). Exploring TPACK among pre-service teachers in Australia and Israel, British Journal of Educational Technology, 50(4), 1-15.

Salter, K. L., \& Kothari, A. (2016). Knowledge 'Translation' as social learning: Negotiating the uptake of research-based knowledge in practice. BMC Medical Education, 16(76), 1-10

Sanchez, H. S. \& Borg, S. (2014). Insights into L2 teachers' pedagogical content knowledge: A cognitive perspective on their grammar explanations, System, 44, 45-53.

Sarıçoban, A., Tosuncuoğlu, İ. \& Kırmızı,Ö. (2019). A technological pedagogical content knowledge (TPACK) assessment of preservice EFL teachers learning to teach English as a foreign language. Journal of Language and Linguistic Studies, 15(3), 1122-1138., Doi: 10.17263/jlls.631552.

Shagrir, L. (2010). Professional development of novice teacher educators: Professional self, interpersonal relations and teaching skills. Professional Development in Education, 36, 45-60. https://doi.org/10.1080/19415250903454809

Shulman, L. S. (1986). Those who understand: Knowledge growth in teaching. Educational Researcher, $15(2), 4-14$

Shulman, L. (1987). Knowledge and teaching: Foundations of the new reform. Harvard Educational Review, 57(1), 1-22 
Spear, A. M., \& da Costa, R. B. (2018). Potential for transformation? Two teacher training programs examined through a critical pedagogy framework. Teaching and Teacher Education, 69, 202-209. https://doi. org/10.1016/j.tate.2017.10.013

Tedick, D. (2013). Embracing proficiency and program standards and rising to the challenge: A response to Burke. Modern Language Journal, 97, 535-538.

Tsiotakis, P., \& Jimoyiannis, A. (2016). Critical factors towards analyzing teachers' presence in online learning communities. Internet and Higher Education, 28, 45-58. https://doi.org/10.1016/j. iheduc.2015.09.002

van Compernolle, R. A. and Henery, A. (2015). Learning to do concept-based pragmatics instruction: Teacher development and L2 pedagogical content knowledge, Language Teaching Research, 19(3) 351-372.

Van Driel, J. H. (2014). Professional learning of science teachers. In C. Bruguiere, A. Tiberghien, \& P. Clement (Eds.), Topics and trends in current science education (pp. 139-156). Dordrecht: Springer.

Vangrieken, K., Dochy, F., Raes, E., \& Kyndt, E. (2015). Teacher collaboration: A systematic review. Educational Research Review, 15, 17-40.

Wu, H. (2009). What's sophisticated about elementary mathematics? American Educator, 33, 4-14.

Yan, C., \& He, C. (2010). Transforming the existing model of teaching practicum: A study of Chinese EFL student teachers' perceptions. Journal of Education for Teaching, 36(1), 57-73.

Yuan, R., \& Lee, I. (2014). Pre-service teachers' changing beliefs in the teaching practicum: Three cases in an EFL context. System, 44, 1-12.

\section{İngilizce öğretmeni adaylarının ders anlatımlarında pedagojik alan bilgisi ana ve}

\section{alt kategorilerinin dışavurumu}

\section{$\ddot{O} \mathbf{z}$}

Bu çalışma, nitel bir araştırma modeli ile, bir devlet üniversitesinde formasyon eğitimine kayıtlı dört İngilizce öğretmeni adayının staj uygulamaları sıradında hangi Pedagojik Alan Bilgisi (PAB) alt boyutlarının ön plana çıktığını incelemek için yapılmıştır. Dört öğretmen adayının ders anlatımları kaydedilmiş ve öğretmen adayları ile derslerden sonra ders değerlendirme oturumları yapılmıştır. Görüşmelerde, hatırlatma tekniği kullanılmıştır. Her öğretmen adayı dört kaz izlenmiştir ve öğretmen adaylarının işledikleri dersler kaydedilmiştir. Moradkhani et al. (2013) tarafından önerilen PAB gruplaması kullanılmıştır. Bu yazarlar, PAB'ı alt kategorilerle beraber 8 ana kategoride ele almışlardır. Bu çalışma, öğretmen adaylarının tamamlamaları gereken bir staj dönemi boyunca yapılmıştır. Sonuçlar, ögrrencileri tanımanın en önemli becerilerden birisi olduğunu ve bunu bilgiyi aktarma becerisi ve ögretmek teknikleri bilgisi' 'nin takip ettiğini göstermiştir. Bulgular aynı zamanda İngilizce öğretmeni adaylarının dile hakimiyet ve dilbilim becerisi alanlarında gelişmeye ihtiyaçları olduğunu göstermektedir. Öğretmen adaylarının etkili girdi sağlama konusunda ilerleme kaydetmeleri gerekmektedir.

Anahtar sözcükler: Ana ve alt kategoriler; Pedagojik alan bilgisi; İngilizce öğretmeni adayları, girdi (input), dil öğretim yöntemleri 


\section{AUTHOR BIODATA}

Dr. Arif Sarıçoban has worked as an associate professor of ELT at Hacettepe University for 20 years and currently works at the Department of ELL at Selçuk University as a full professor. Dr. Sarıçoban the editor-inchief for an international journal.

Dr. Özkan Kırmızı works as an associate professor at English Language and Literature Department at Karabuk University. He completed his Ph.D at Hacettepe University, English Language and Teaching Department. His interest areas are L2 teacher education and pedagogical content knowledge 